\title{
Effect of Chilling Regimes on the Nutritional Value of Turkey Meat
}

\author{
Alexander Drozd, Diana Orlova*, Tamara Kalyuzhnaya, Manya Mkrtchyan and Yuri Kuznetsov \\ Saint-Petersburg State University of Veterinary Medicine, Saint Petersburg, Russia \\ *Corresponding author: skodaumka@yandex.ru
}

\begin{tabular}{l} 
Article History: $21-408 \quad$ Received: $28-$ Sep- $21 \quad$ Revised: $14-$ Oct- 21 \\
\hline ABS TRACT \\
This paper studies changes in the mass fraction of moisture the content of proteins and fats in turkey meat, depending \\
on the thermal state. The research materials were the chilled parts of turkey carcasses. There had established that \\
defrosted meat contains less protein by $0.5 \%$, fat $0.2 \%$, and moisture $0.8 \%$ than chilled turkey meat. The difference \\
between the re-defrosted meat and chilled meat by protein content is $1.4 \%$, fat content is $0.6 \%$, and moisture is $2.9 \%$. \\
This result indicates a significant decrease in the nutritional value of turkey meat. Furthermore, substantial changes in \\
moisture content were during repeated freezing and thawing meat. Thus, results indicate that meat does not meet the \\
established standards and indicates a negative trend in turkey meat quality and consumer properties.
\end{tabular}

Key words:_Defrosted meat, Protein content, Fat content, Loss of water, Water-soluble proteins.

\section{INTRODUCTION}

Meat and meat products remain unchanged components of the human diet. The rich nutritional and biological value of meat is due to the high content of complete proteins, fats, enzymes, vitamins, minerals, etc. (Patterson et al. 2017). In recent decades, nutritionists have recommended lean meats that do not adversely affect human fat metabolism. In this regard, turkey meat is gaining popularity on the raw meat market (Tsigarida et al. 2019; Barbin et al. 2020).

In poultry meat, the ratio of protein to fat is close to optimal, while the protein content is from 10.5 to $22.2 \%$, and fat is from 2 to $26.0 \%$, depending on the type of poultry, growing conditions, breed, sex, part carcasses and methods of cutting (Zubair et al. 2015; Gálvez et al. 2018). As a result, the energy value of turkey meat products ranges from 260 to $291 \mathrm{kcal}$ (1090-1220J), which satisfies 8-10\% of the daily energy requirement, as a result of which these products could classify as low-calorie foods (Lyasota and Kolodka 2020; Haraf et al. 2021).

Turkey meat is not high in fat and cholesterol, especially skinless fillets. In addition, it contains a high level of n-3 PUFA: eicosapentaenoic acid (EPA) and docosahexaenoic acid (DHA) (Jonker et al. 2008; Okuskhanova et al. 2017). The high biological and dietary qualities of turkey meat allow it to successfully compete with the meat of other poultry and slaughter animals, thereby being widely used to produce specialized food products, including for children of early, preschool and school-age (Mikulski et al. 2012). Like any other type of meat, turkey meat during storage very soon undergoes microbiological and enzymatic deterioration. Therefore, to extend the shelf life of products and maintain their quality and safety in the industry, the most popular methods for meat raw materials are refrigeration and freezing (Mohammed et al. 2021).

Undoubtedly, chilled turkey meat surpasses frozen meat in nutritional and biological value, retains its culinary and consumer properties in total, and therefore is in the most significant demand (Chen et al. 2020). However, the shelf life of chilled meat - carcasses or parts of carcasses - is short and in compliance with veterinary and sanitary requirements at temperatures from minus $1{ }^{\circ} \mathrm{C}$ to plus $2^{\circ} \mathrm{C}$, ranges from 2 to 5 days. Furthermore, when meat is processing by subzero temperatures, free water in cells and intercellular space crystallizes, significantly reducing microorganisms' vital activity and enzymes that cause spoilage in meat (Orlova et al. 2020). Therefore, the shelf life of frozen turkey meat depends on temperature conditions: from minus $12^{\circ} \mathrm{C}$ to $25^{\circ} \mathrm{C}$ from 1 to 14 months (Tarté 2009).

As a result of freezing, muscle cells are wholly or partially destroyed by the mechanical action of ice crystals. Nutrients are lost thus, and the raw material loses its original properties (Xia et al. 2014). In world practice, in recent years, the method of near-infrared spectrometry has been an effective method for analyzing meat from meat products. Thus, this method was used to identify raw meat, assess its quality and chemical composition (Rashid et al. 2021) and assess its thermal state (Chapman et al. 2020).

Cite This Article as: Drozd A, Orlova D, Kalyuzhnaya T, Mkrtchyan M, Kuznetsov Y, 2022. Effect of chilling regimes on the nutritional value of turkey meat. International Journal of Veterinary Science 11(2): 264-267. https://doi.org/10.47278/journal.ijvs/2021.106 
Int J Vet Sci, 2022, 11(2): 264-267.

\section{MATERIALS AND METHODS}

Studies have been carried out to study the dynamics of the mass fraction of moisture, the content of proteins and fats in chilled, defrosted, and re-defrosted turkey meat. Chilled parts of turkey carcasses - wing, thigh, drumstick, breast, served as the material for the study.

The amount of moisture and meat juice released during thawing was determined by samples weighing before and after freezing with an accuracy of $0.01 \mathrm{~g}$, expressed as a percentage and compared with the value "no more than $4 \%$ " established by regulatory documents.

The number of proteins, fats, and moisture in the meat of parts of turkey carcasses was measured by the method of near-infrared spectrometry, based on measuring the relative intensity of infrared radiation and recording the absorption spectra of the analyzed samples in the nearinfrared region in two spectral ranges of wavelengths: from 400 to $700 \mathrm{~nm}$ and from 850 to $1100 \mathrm{~nm}$ with subsequent recalculation of the obtained spectral data for the values of the mass fraction of fat, protein, moisture according to previously developed calibration models based on artificial neural networks using the analyzer software (Ronaldson et al. 2012).

The results of the quantitative analysis were by using Microsoft Office Excel, Statistica 10 (StatSoft) and a method of variation statistics with the calculation of correlation coefficient arithmetic mean values. Where are: M - the arithmetic mean, $\mathrm{m}$ is the error of the arithmetic mean, Student's t-test determined the reliability of differences between the samples in Microsoft Office Excel $(\mathrm{P}<0.05)$.

\section{RESULTS AND DISCUSSION}

The nutritional value of chilled meat is of the highest importance because chilled meat preserves the muscle tissue structure and muscle fibers (Fig. 1). When weighing the samples before and after defrosting, it was found that the weight loss is not the same in different parts of the carcasses (Table 1). In defrosted and re-defrosted meat was measuring, the mass fraction of moisture released after low-temperature processing. In defrosted meat was releasing from 2.84 to $3.6 \%$ of moisture and meat juice, depending on the carcass part, which corresponds to the maximum permissible values. However, in meat after repeated defrosting, this indicator ranged from 4.65 to $6.12 \%$, which exceeds the requirements of regulatory documents in terms of moisture and meat juice losses during refrigeration by no more than $4 \%$. It is explaining by a violation of the structure of muscle fibers, which is more pronounced in repeatedly defrosted meat (Fig. 2, 3).

As a result of the studies carried out using the NIR analyzer, we obtained data on the number of proteins, fats, and moisture in the studied turkey meat samples (Table 2). The average protein content in chilled turkey meat was $20.6 \%$, the highest in the breast at $22.4 \%$, and the lowest in the thigh at $18.7 \%$. On the other hand, the average fat content in such meat was $2.9 \%$, the smallest fat was in the breast, $2.2 \%$ and the highest in the thigh, $4.1 \%$. In terms of moisture content, the average value is $74.5 \%$, the smallest amount of water in the shin, $74.1 \%$, while the largest is in the wings, $74.8 \%$ (Fig. 1 to 3 ). The obtained values were as control.
Table 1: Weight loss in defrosted and re-defrosted turkey meat Part of the carcass Defrosting turkey Re-defrosted turkey

\begin{tabular}{|c|c|c|}
\hline & meat $(\mathrm{g})$ & meat $(\mathrm{g})$ \\
\hline Hip & $3.36 \pm 0.04$ & $5.67 \pm 0.06^{*}$ \\
\hline Shin & $3.58 \pm 0.03$ & $4.65 \pm 0.04^{*}$ \\
\hline Breast & $2.84 \pm 0.01$ & $5.05 \pm 0.03^{*}$ \\
\hline Wing & $3.6 \pm 0.05$ & $6.12 \pm 0.05^{*}$ \\
\hline
\end{tabular}
similar indicators in defrosted meat $(n=128)$.

Table 2: Moisture, protein and fat content of turkey meat

\begin{tabular}{llll}
\hline $\begin{array}{l}\text { Part of } \\
\text { carcass }\end{array}$ & $\begin{array}{r}\text { Chilled } \\
\text { meat, g }\end{array}$ & $\begin{array}{c}\text { turkey Defrosting } \\
\text { turkey meat, g }\end{array}$ & $\begin{array}{l}\text { Re-defrosted } \\
\text { turkey meat, g }\end{array}$ \\
Protein content $(\%)$ & & & \\
Hip & $18.7 \pm 0.3$ & $18.5 \pm 0.4^{*}$ & $17.7 \pm 0.6^{*}$ \\
Shin & $19.4 \pm 0.5$ & $19.2 \pm 0.6^{*}$ & $17.9 \pm 0.3^{*}$ \\
Breast & $22.4 \pm 0.2$ & $22.3 \pm 0.4^{*}$ & $21.1 \pm 0.5^{*}$ \\
Wing & $21.9 \pm 0.4$ & $20.4 \pm 0.3^{*}$ & $19.9 \pm 0.7^{*}$ \\
Fat content $(\%)$ & & \\
Hip & $4.1 \pm 0.1$ & $3.9 \pm 0.3^{*}$ & $3.6 \pm 0.1^{*}$ \\
Shin & $3.3 \pm 0.2$ & $3.2 \pm 0.4^{*}$ & $2.8 \pm 0.3^{*}$ \\
Breast & $2.2 \pm 0.1$ & $2.1 \pm 0.2^{*}$ & $1.8 \pm 0.4^{*}$ \\
Wing & $2.3 \pm 0.2$ & $2.1 \pm 0.3^{*}$ & $1.9 \pm 0.2^{*}$ \\
Moisture contents $(\%)$ & & \\
Hip & $74.5 \pm 0.7$ & $74.2 \pm 0.5^{*}$ & $72.1 \pm 0.7^{*}$ \\
Shin & $74.1 \pm 0.4$ & $72.5 \pm 0.7^{*}$ & $70.5 \pm 0.8^{*}$ \\
Breast & $74.4 \pm 0.6$ & $74.1 \pm 0.3^{*}$ & $71.4 \pm 0.4^{*}$ \\
Wing & $74.8 \pm 0.5$ & $74.0 \pm 0.5^{*}$ & $72.3 \pm 0.6^{*}$ \\
\hline
\end{tabular}

Mean \pm SD bearing asterisk in a row differ significantly $(\mathrm{P}<0.05)$ with similar indicators in defrosted meat $(n=128)$

By studying changes in the nutritional value of turkey meat, we obtained data on the content of protein, fat and moisture in defrosted meat. The average indicator of the mass fraction of protein was $20.1 \%$, the highest value remains in the breast $22.3 \%$, and the lowest in the thigh is $18.5 \%$. The fat content is $2.8 \%$, most of all in the thigh $3.9 \%$, less in the breast and wing $2.1 \%$. The mass fraction of moisture in different parts of the turkey carcass is $73.7 \%$, the maximum value in the thigh muscles is $74.2 \%$, and the minimum value is $72.5 \%$ in the lower leg (Fig. 1 to 3 ).

Re-defrosting meat contains an average of $19.2 \%$ protein, from $17.7 \%$ in the thigh to $21.1 \%$ in the breast, $2.5 \%$ fat, the minimum value in the breast $1.8 \%$, maximum in the thigh $3.6 \%$. The average moisture content is $71.6 \%$, from $70.5 \%$ in the lower leg to $72.3 \%$ in the wing (Fig. 1 to 3 ). The quantitative moisture content noted significant changes during single and double freezing of parts of turkey carcasses. So, the thigh muscles lost 0.4 and $3.22 \%$, the lower leg muscles -2.16 , $4.86 \%$, the chest muscles - 0.3 and $4.03 \%$, the wings $1.07,3.34 \%$, respectively.

The mass fraction of protein in the muscles of the thigh, lower leg, breast, and wing during single and double was defrosting decreased in direct proportion to the loss of moisture and meat juice during low-temperature meat processing. In the defrosted muscles of the thigh, the protein content decreased by $1.07 \%$ compared to chilled meat, in the repeatedly defrosted - by $5.35 \%$. In the lower leg, the protein index with a single defrosting decreased by $1.03 \%$, with repeated defrosting - by $7.73 \%$; in defrosted breast, the mass fraction of protein decreased by $0.45 \%$, in re-defrosted breast - by $5.8 \%$ compared to chilled products. The wing muscles lost $3.19 \%$ of their protein with single freezing and $9.13 \%$ after repeated freezing. 


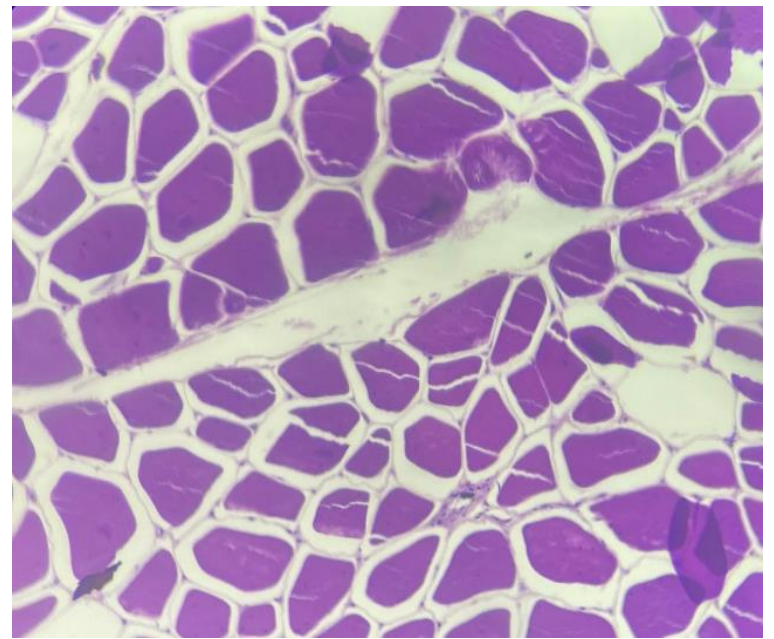

Fig. 1: Muscle tissue structure of chilled turkey meat (staining with hematoxylin-eosin; 200x)

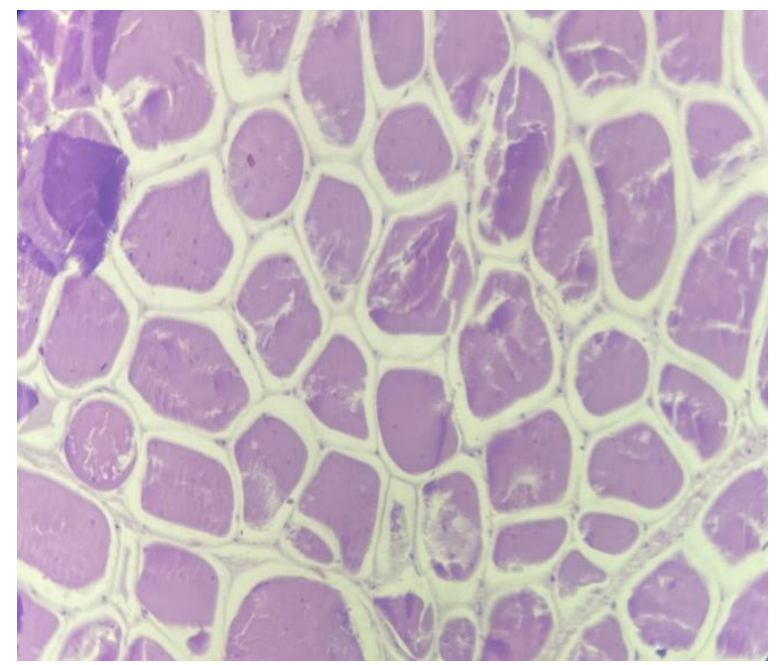

Fig. 2: The muscle tissue structure of defrosted turkey meat (hematoxylin-eosin, 200x).

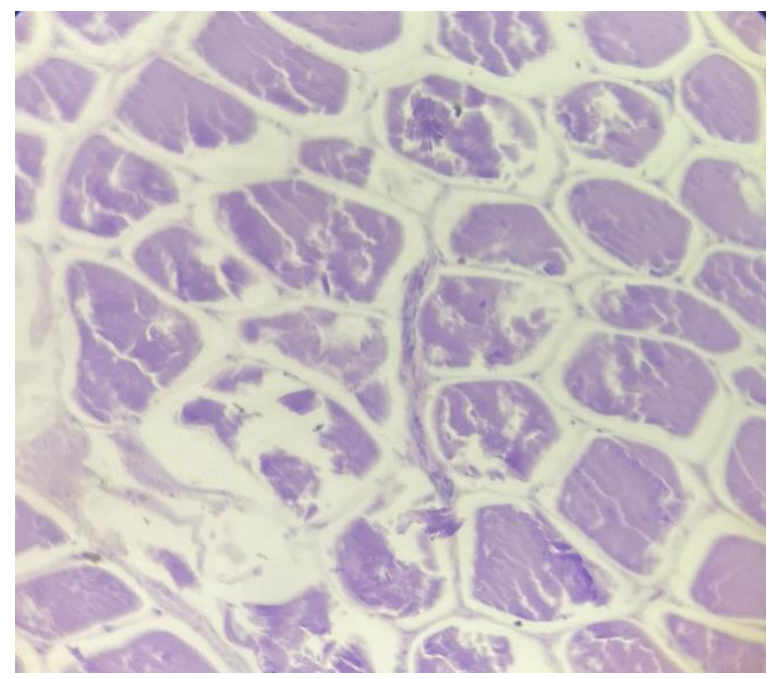

Fig. 3: The muscle tissue structure of re-defrosted turkey meat (hematoxylin-eosin, 200×).

The fat content in parts of turkey carcasses also decreased during single and double defrosting. For example, in frozen thigh muscles, the fat content decreased by $4.87 \%$ compared to chilled raw materials, in refrozen muscles - by $12.19 \%$. In the defrosting muscles of the lower leg, the amount decreased by $3.03 \%$, into re-defrosting muscles - by $15.15 \%$; the mass fraction of fat into breast muscles decreased by $4.54 \%$, in the re-defrosted - by $18.18 \%$ compared to chilled products, into wing muscles by 8.69 and $17.39 \%$, respectively.

The above results show that in defrosted meat, the average protein content is less by $0.5 \%$, fat $-0.2 \%$, and moisture $0.8 \%$ than in chilled turkey meat, which in general does not reduce the product's nutritional value. However, in re-defrosted meat, in comparison with chilled meat, there is a different difference in similar indicators. Thus, the difference in protein content is $1.4 \%$, fat $0.6 \%$, and moisture $2.9 \%$, which indicates a significant decrease in the nutritional value of turkey meat. It indicates a significant decrease in the nutritional value of turkey meat as a result of destructive changes in muscle tissue during refrigeration.

\section{Conclusion}

Moisture and meat juice losses depending on thermal meat state during defrosting were from 2.84 to $3.6 \%$, depending on the part carcass. And after repeated defrosting, this indicator was 4.65-6.12\%, which exceeds the permissible value by $0.65-2.12 \%$. Therefore, there are observing changes in the nutritional value of turkey meat. In addition, during repeated freezing and thawing, significant changes in the moisture content were observed - the obtained values exceeded the value of the moisture mass fraction to once defrosted meat by $1.1 \%$; protein content $-0.9 \%$, fat $-0.4 \%$. This value exceeds the established standards and confirms the negative dynamics of turkey meat's quality and consumer properties. Changes in the nutritional value of turkey meat during heat treatment are associated with the destruction of cellular structures and, as a result, the loss of water, fats, water-soluble proteins. These data confirm the need to assess the thermal state of turkey meat during transportation, the implementation of incoming control of raw materials in storage, trade, and prevention release for sale of meat products in circulation in violation of veterinary and sanitary requirements.

\section{Acknowledgments}

The reported study was funded by RFBR, project number 19-316-90022.

\section{Author's Contribution}

DO conceived of the presented idea. TK developed the theory and performed the computations. MM verified the analytical methods. $\mathrm{YK}$ and $\mathrm{AD}$ to investigate and supervised the findings of this work. All authors discussed the results and contributed to the final manuscript.

\section{REFERENCES}

Barbin DF, Badaró AT, Honorato DCB, Ida EY and Shimokomaki M, 2020. Identification of Turkey meat and processed products using near infrared spectroscopy. Food Control 107: 106816. https://doi.org/10.1016/j.foodcont. 2019.106816

Chapman J, Elbourne A, Truong VK and Cozzolino D, 2020. Shining light into meat - a review on the recent advances in in vivo and carcass applications of near infrared 
spectroscopy. International Journal of Food Science and Technology 55: 935-941. https://doi.org/10.1111/ijfs.14367

Chen Q, Zhang Y, Guo Y, Cheng Y, Qian H, Yao W, Xie Y and Ozaki Y, 2020. Non-destructive prediction of texture of frozen/thaw raw beef by Raman spectroscopy. Journal of Food Engineering 266: 109693. https://doi.org/10.1016/j. jfoodeng.2019.109693

Gálvez F, Domínguez R, Pateiro M, Carballo Poultry J, Tomasevic I and Lorenzo JM, 2018. Effect of gender on breast and thigh turkey meat quality. British Science 59: 408415. https://doi.org/10.1080/00071668.2018.1465177

Haraf G, Wołoszyn J, Okruszek A, Goluch Z, Wereńska M and Teleszko M, 2021. The protein and fat quality of thigh muscles from Polish goose varieties. Poultry Science 100: 100992. https://doi.org/10.1016/j.psj.2021.01.015

Jonker KM, Tilburg JJHC, Hägele GH and de Boer E, 2008. Species identification in meat products using real-time PCR. Food Additives and Contaminants - Part A Chemistry, Analysis, Control, Exposure and Risk Assessment 25: 527 533. https://doi.org/10.1080/02652030701584041

Lyasota VP and Kolodka AV, 2020. Hygiene-biotic factors on the application of modern pre-and probiotics in poultry. Scientific Messenger of LNU of Veterinary Medicine and Biotechnologies 22: 88-93. https://doi.org/10.32718/ nvlvet $\underline{9816}$

Mikulski D, Jankowski J, Zdunczyk Z, Juskiewicz J and Slominski BA, 2012. The effect of different dietary levels of rapeseed meal on growth performance, carcass traits and meat quality in turkeys. Poultry Science 91: 215-223. https://doi.org/10.3382/ps.2011-01587

Mohammed HHH, He L, Nawaz A, Jin G, Huang X, Ma M, Abdegadir WS, Elgasim EA and Khalifa I, 2021. Effect of frozen and refrozen storage of beef and chicken meats on inoculated microorganisms and meat quality. Meat Science 175: 108453. https://doi.org/10.1016/j.meatsci.2021.108453

Okuskhanova E, Rebezov M, Yessimbekov Z, Suychinov A, Semenova N, Rebezov Y, Gorelik O and Zinina O, 2017. Study of water binding capacity, $\mathrm{pH}$, chemical composition and microstructure of livestock meat and poultry. Annual Research and Review in Biology 14: 1-7. https://doi.org/ 10.9734/ARRB/2017/34413

Orlova D, Kalyuzhnaya T, Tokarev A and Kuznetsov Y, 2020. New method for veterinary and sanitary control of defrosted meat and fish. International Journal of Veterinary Science 9: 317-319. https://doi.org/10.37422/IJVS/20.010
Patterson BA, Matarneh SK, Stufft KM, England EM, Scheffler TL, Preisser RH, Gerrard DE, England EM, Scheffler TL, Stewart EC and Eilert S, 2017. Pectoralis major muscle of Turkey displays divergent function as correlated with meat quality. Poultry Science 96: 1492-1503. https://doi.org/ $10.3382 / \mathrm{ps} / \mathrm{pew} 410$

Rashid ANA, Kormin F and Asman S, 2021. Quality analysis of meats using ftir spectroscopy, colour spectrophotometer, texture analyser and physical image analysis. Journal of Sustainability Science and Management 16: 103-119. https://doi.org/10.46754/jssm.2021.01.010

Ronaldson JP, Zainon R, Scott NJA, Gieseg SP, Butler AP, Butler $\mathrm{PH}$ and Anderson NG, 2012. Toward quantifying the composition of soft tissues by spectral CT with Medipix3. Medical Physics 39: 6847-6857. https://doi.org/10.1118/ $\underline{1.4760773}$

Tarté R, 2009. Meat-derived protein ingredients. In: Ingredients in Meat Products, Tarté R (eds) Springer, New York, USA pp: 145-171. https://doi.org/10.1007/978-0-387-71327-4_7

Tsigarida E, Gaitis F, Garofalakis G, Papanastasiou D, Marakis G, Mila S, Barberis K, Tzoumanika F, Aspridou Z, Tsaloumi S and Koutsoumanis K, 2019. Evaluation of listeriosis risk related with the consumption of non-prepackaged ready-toeat (RTE) cooked meat products handled at retail stores in Greece. EFSA Supporting Publications 16: 1677E. https://doi.org/10.2903/sp.efsa.2019.en-1677

Xia L, Jiang AM, Lu Y, Li JG, Wen XL and Zhang DL, 2014. A comparative study on quality of chilled and quick-frozen pork during the storage period. Modern Food Science and Technology 30: 174-180.

Zubair F, Nuzhat H, Salim-ur- R, Yadav RB, Yadav BS, Dhull N, Wani S, Kumar P, Thesis A, Singh P, Singh R, Jha A, Rasane P, Products S, Products C, Outline C, Omeire G, Kabuo N, Eluchie C, Amandikwa C, Odoemenam G, Okpala L, Okoli E, Science F, Nogueira A, Steel C, Klunklin W, Savage G, Khan S, Kang M, Kim M, Kwak H, Kim S, Information B, Himeda M, Yanou N, Fombang E, Facho B, Kitissou P, Mbofung C, Scher J, Heinz G, Hautzinger P, Guide M, Structural A, Goan E, Gautam L, Chaturvedi N, Gupta A, Fradinho P, Nunes M, Ebner P, Drakos A, Vasiliki LDAWR, David O, Arthur E, Kwadwo S, Badu E, Sakyi P, Dave D, Ghaly A, Chandra S, Singh S, Kumari D, Canalis M, León A, Cairano M, Galgano F, Tolve R, Caruso M, Condelli N, Barbut S, Analysis M, Alozie Y, Chinma C, Alam S, Kumar S, Adebiyi J, Obadina A, Adebo O and Kayitesi E, 2015. Meat Industry Guide. Meat Processing Analysis 2: 1-36. 